\title{
Hydrochemical Characterization and Water Quality of the Continental Intercalare Aquifer in the Ghardaïa Region (Algerian Sahara)
}

\author{
Kebili Mokhtar', Bouselsal Boualem ${ }^{2 *}$, Gouaidia Layachi ${ }^{1}$ \\ 1 Laboratory of Sedimentary Environment and Mineral and Water Resources in Eastern Algeria, Department \\ of Earth Sciences, Larbi Tebessi University, Route de Constantine, 12002, Tébessa, Algeria \\ 2 Laboratory of Underground Reservoirs: Oil, Gas and Aquifers, University of Kasdi Merbah Ouargla, \\ 30000 Algeria \\ * Corresponding author' e-mail: bousboualem@gmail.com
}

\begin{abstract}
This study investigates the hydrogeochemical characteristics and water quality of the Ghardaïa Continental Intercalare (CI) aquifer for domestic purposes and agricultural irrigation. Twenty-eight (28) grondwater samples were collected and analyzed for different physicochemical parameters. The result of the hydrochemical analysis illustrates that three facies dominate the CI waters: $\mathrm{SO}_{4}-\mathrm{Na}, \mathrm{Cl}-\mathrm{Na}$, and $\mathrm{HCO}_{3}-\mathrm{Na}$. The analysis of the correlation matrix and the characteristic ratios, as well as the calculations of the saturation indices of the main minerals, show that the mineralization of the waters is linked to the dissolution of evaporites (gypsum and halite in particular) and the cationic exchange phenomenon. The assessment of the potability of the water by using the water quality index (WQI) method shows three classes of water quality, namely, excellent (14.28\%), good (7.14\%), and poor (78.58\%). The agricultural water quality was assessed using the parameters; EC, SAR, Na\%, KR, PI and MH. The results show that the waters of the continental intercalare aquifer are generally of good quality for irrigation. However, the high salinity of the waters requires good drainage of the cultivated soils.
\end{abstract}

Keywords: Ghardaïa, Continental Intercalare, evaporites, WQI, irrigation

\section{INTRODUCTION}

In the Ghardaïa region, severe climatic factors, namely low rainfall, high temperatures, and high evaporation, mean underground water reserves are the main source of drinking water and for agricultural uses. Due to the growing demand for water in the region for various purposes and the poor quality of the shallow aquifer, the continental intercalare (CI) aquifer is now widely exploited. This situation has led to a deterioration in the chemical quality of the CI waters, which are becoming increasingly mineralized. As far as piezometry is concerned, overexploitation of the continental intercalare $(\mathrm{CI})$ aquifer in some localities of Ghardaïa has led to a considerable lowering of the hydrostatic level and an increase in water mineralization. This situation is observed in the large urban centers of the Ghardaïa region (the city of Ghardaïa, Metlili, Guerrara, and Zelfana). This work aims to understand the geochemical behavior of the water and determine the quality of the water of the Ghardaiia Continental Intercalare (CI) aquifer for domestic purposes and agricultural irrigation.

\section{PRESENTATION OF THE STUDY AREA}

\section{Geographical location and climate}

The Ghardaïa region is located in southern Algeria (Fig.1) (Hakimi and al., 2020) and covers $84,660 \mathrm{~km}^{2}$, with 451,456 inhabitants. The geographical coordinates of the study area are $1^{\circ} 53^{\prime} 12^{\prime \prime} / 4^{\circ} 59^{\prime} 30^{\prime \prime E}$ and $28^{\circ} 57^{\prime} 31^{\prime \prime} / 33^{\circ} 0 ’ 36^{\prime \prime N}$. 
The climate of the region is Saharan; the annual rainfall rate collected is $71.4 \mathrm{~mm}$, with a maximum water level recorded in September $(19.2 \mathrm{~mm})$ while July is the driest month $(1.3 \mathrm{~mm})$. The average annual humidity is around $35.4 \%$. The average annual temperature is around $22.2^{\circ} \mathrm{C}$, with a maximum of $33.6^{\circ} \mathrm{C}$ recorded in July. Annual evaporation is about $2621 \mathrm{~mm}(\mathrm{OMN}, 2020)$.

\section{Hydrogeology of the study area}

The Ghardaiia region is part of the Northern Sahara aquifer system (Satouh and al., 2021; Bouselsal, 2017; OSS, 2003). The Ghardaïa subsoil consists of a shallow aquifer and a deep aquifer called the continental intercalare (CI). At the scale of the study area, the litho-stratigraphic correlation of the water boreholes shows that the CI aquifer is found at depths decreasing from north-east to south-west (Fig. 2). In the Guerrara area, the top of the aquifer is at a depth of about 700 meters, whereas it is less than 150 meters deep in the El Meniaa area.

The drilling data analysis shows that; the Eocene is composed of whitish to grey limestone, sometimes hard, and is only found in Guerrara and Zelfana. The Senonian is composed of clay and alternating dolomite and marl. The Turonian is made up of limestone rich in dolomite. The latter overlies the Cenomanian, which forms the impermeable roof of the continental intercalare aquifer and is composed of greenish-grey clays. The Albian age formations of fine clayey sands and clayey sandstones constitute the continental intercalare aquifer's reservoir.

\section{MATERIALS AND METHODS}

\section{Water sampling and chemical analysis}

A hydrochemical measurement campaign was carried out in the study area in March 2019. Twenty-eight (28) water samples were collected and analyzed. The coordinates of the sampled boreholes were determined by GPS. The physicochemical parameters were measured in situ immediately after sample collection, using a portable multimeter. The collected samples were analyzed in the laboratory using standard techniques (Rodier,

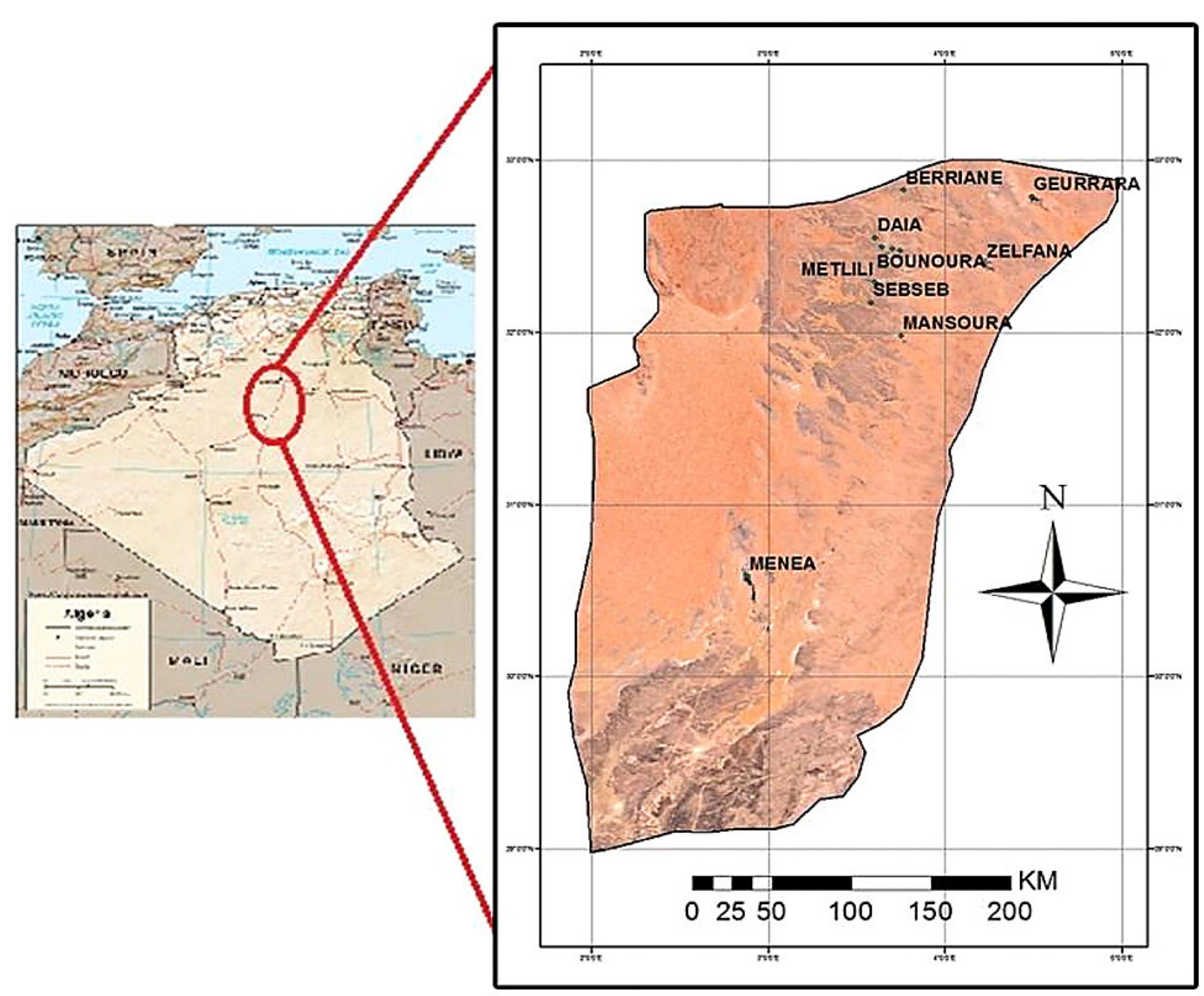

Figure 1. Geographical location of the Ghardaïa region 


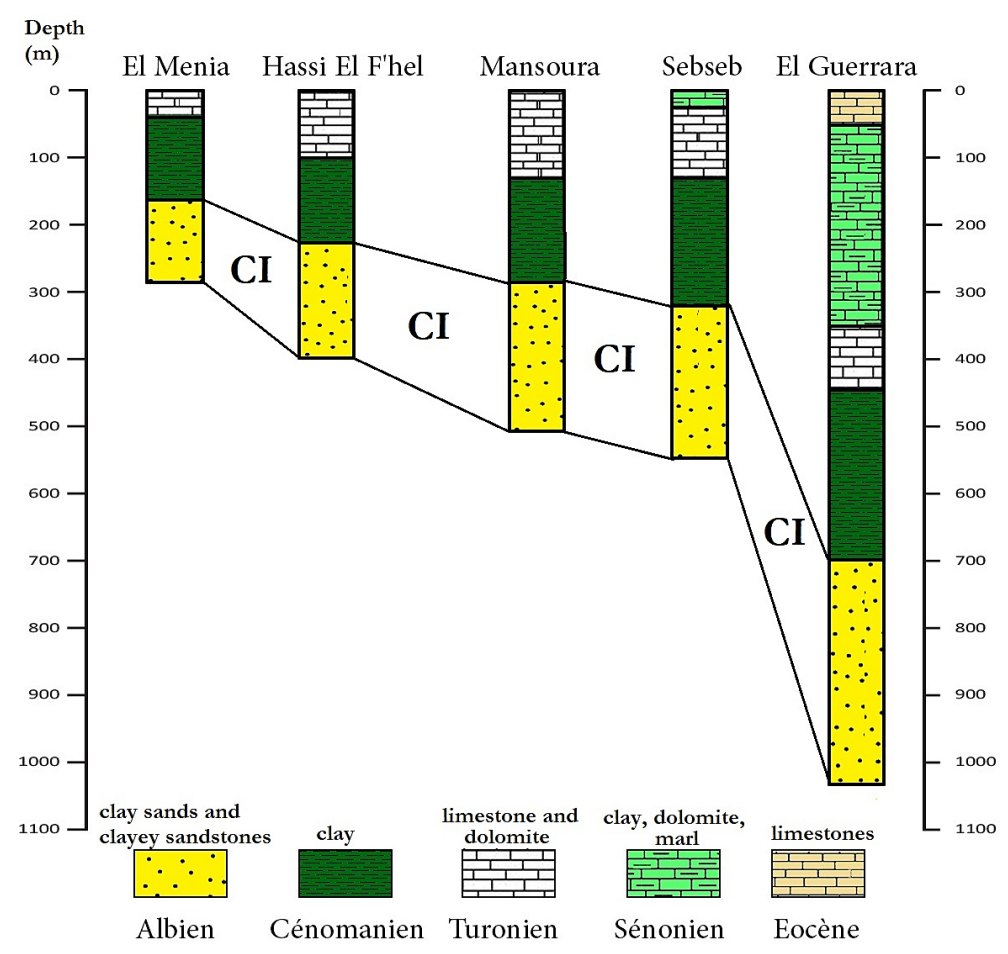

Figure 2. Litho-stratigraphic correlation of water boreholes

1996). The calculation of the ionic balance of the results allows the reliability of the analyses to be assessed. This parameter is expressed in $\%$ and is based on the following formula:

$$
\begin{gathered}
\text { Ionic balance }= \\
=\left[\left(\sum \text { cations }-\sum \text { anions }\right) /\right. \\
\left./\left(\Sigma \text { cations }+\sum \text { anions }\right)\right] * 100
\end{gathered}
$$

The results obtained are of acceptable quality if the percentage of error is less than $5 \%$.

\section{Hydrogeochemical study of the water}

All statistical evaluations were performed with XLSTAT 2014 for Windows to identify the most important factors controlling groundwater geochemistry. Hydrochemical data were used to determine water types with the Piper diagram. The hypothetical combination of salts is used to estimate different assemblages of $\mathrm{NaCl}, \mathrm{MgCl}_{2}$, $\mathrm{CaCl}_{2}, \mathrm{CaSO}_{4} \mathrm{MgSO}_{4}$ and $\mathrm{Na}_{2} \mathrm{SO}_{4}$ to specify the probable origin of each major element contributing to the mineralization of the water. This combination is based on the lithological nature of the aquifer. PHREEQC software (Parkhurst and Appelo., 2013) was used to determine saturation indices for a few minerals (calcite, dolomite, gypsum, anhydrite, and halite).

\section{Water quality assessment}

The evaluate of the chemical quality of the water of the continental intercalare aquifer for human consumption was carried out firstly by comparison with the guideline values of the World Health Organisation (WHO, 2011) and the Algerian standards (JORADP, 2011) for drinking water (Table 1) and secondly by using the water quality index (WQI) method. The water quality used for irrigation was evaluated by studying the most important factors that influence crop yield and maintenance of soil productivity. These factors are electrical conductivity (EC), sodium adsorption ratio (SAR), sodium percentage $(\mathrm{Na} \%)$, Kelly ratio (KR), permeability index (PI), and magnesium hazard (MH). These irrigation parameters are calculated using the following formulas (Adimalla et al., 2020; Dhaouadi et al., 2020):

$$
\begin{gathered}
N a \%=\frac{(N a+K) \times 100}{N a+K+C a+M g} \\
S A R=\frac{N a}{\sqrt{\frac{C a+M g}{2}}}
\end{gathered}
$$




$$
\begin{gathered}
K R=\frac{N a^{+}}{C a^{+2}+M g^{+2}} \\
P I=\frac{N a+K+\sqrt{H C O 3}}{C a+M g+N a+K} \times 100 \\
M H=\frac{M g}{C a+M g} \times 100
\end{gathered}
$$

\section{RESULTS AND DISCUSSION}

\section{Physicochemical characterization of the $\mathrm{Cl}$ waters}

Table 1 lists the physico-chemical parameters of the intercalated continental water samples in terms of maximum, minimum, standard deviation, mean values, and potability standards. The $\mathrm{pH}$ values vary from 7.12 to 7.89 , indicating the presence of slightly basic water. The values of electrical conductivity (EC) show great variability. They vary between $452 \mu \mathrm{S} / \mathrm{cm}$ (El Meniaa 04) and $2524 \mu \mathrm{S} / \mathrm{cm}$ (Guerrara 03). The samples collected show TDS values ranging from 308 to $1688 \mathrm{mg} / \mathrm{l}$. The highest values were observed where the deepest aquifer (Zelfana $1688 \mathrm{mg} / 1$ and Guerrara $1679 \mathrm{mg} / \mathrm{l})$. The lowest values (TDS < $335 \mathrm{mg} / \mathrm{l}$ ) were found in the El Meniaa area.

Sulfate levels in the CI aquifer range from 52.9 to $556.67 \mathrm{mg} / 1$. Sulfate is the dominant anion in the study area, its main source being the dissolution of gypsum. The chloride $\left(\mathrm{Cl}^{-}\right)$content varies from 30.48 to $439.61 \mathrm{mg} / \mathrm{l}$ with an average of $259.78 \mathrm{mg} / \mathrm{l}$. The concentration of $\mathrm{HCO}_{3}^{-}$varies between 120.78 and $346.48 \mathrm{mg} / \mathrm{l}$. Potassium $\left(\mathrm{K}^{+}\right)$ranged from 4.17 to $32 \mathrm{mg} / \mathrm{l}$ with an average of $15.54 \mathrm{mg} / \mathrm{l}$. Calcium $\left(\mathrm{Ca}^{2+}\right)$ values vary from 33.66 to $168.33 \mathrm{mg} / \mathrm{l}$ with an average of $117.03 \mathrm{mg} / \mathrm{l}$. The sodium $\left(\mathrm{Na}^{+}\right)$content of the intercalated continental waters of the study area varies between 37.27 and $281.25 \mathrm{mg} / \mathrm{l}$ with an average of $168.34 \mathrm{mg} / \mathrm{l}$. The magnesium $\left(\mathrm{Mg}^{2+}\right)$ content in the groundwater samples varies from 5.83 to $90.39 \mathrm{mg} / 1$ with an average of $47.71 \mathrm{mg} / 1$.

\section{Chemical facies}

The Piper (1954) diagram (Fig. 3) shows the chemical balance between cations and anions. The Piper diagram consists of two triangles that apply equivalent percentages of anions and cations and their combined state in rhomboid squares. This diagram is used to classify the hydrochemical facies of groundwater. Two chemical facies dominate the sampled waters:

- The sodium chloride sulfate facies represents $85.72 \%$ of the sampled waters. These facies represent the majority of the boreholes analyzed, except the boreholes in the El Meniaa area. These groundwaters are characterized by an electrical conductivity exceeding $1000 \mu \mathrm{S} / \mathrm{cm}$.

- The sodium bicarbonate facies represents $14.28 \%$ of the sampled waters. This facies is found in the borehole of the El Meniaa region. The groundwater of this region is characterized by a low electrical conductivity $(>471 \mu \mathrm{S} / \mathrm{cm})$.

\section{Processes controlling groundwater geochemistry}

The correlation matrix applied to the continental intercalare groundwater data shows strong correlations between major elements and physicochemical parameters, namely $\mathrm{Na} v s$. $\mathrm{Cl}, \mathrm{Ca} v s$. $\mathrm{SO}_{4}, \mathrm{Ca}$ vs. $\mathrm{Cl}, \mathrm{Mg}$ vs. $\mathrm{Cl}, \mathrm{Na}$ vs. $\mathrm{SO}_{4}$, and $\mathrm{Mg}$ vs. $\mathrm{SO}_{4}$ (Bouselsal and al., 2018). This strong correlation between these major elements shows their common origin in the groundwater. On the other hand, there is a good correlation between the electrical conductivity (EC) and the major elements,

Table 1. Physicochemical parameters of CI from the Ghardaïa region

\begin{tabular}{|l|c|c|c|c|c|c|c|c|c|c|c|}
\hline Parameters & $\mathrm{Ca}^{2+}$ & $\mathrm{Mg}^{2+}$ & $\mathrm{Na}^{+}$ & $\mathrm{K}^{+}$ & $\mathrm{Cl}^{-}$ & $\mathrm{SO}_{4}^{2-}$ & $\mathrm{HCO}_{3}^{-}$ & $\mathrm{NO}_{3}^{-}$ & $\mathrm{pH}$ & $\mathrm{TDS}$ & $\mathrm{EC}$ \\
\hline Mean & 117.03 & 47.71 & 168.34 & 15.54 & 259.78 & 359.90 & 196.68 & 0.96 & 7.46 & 1165 & 1739 \\
\hline Max & 168.33 & 90.39 & 281.25 & 32.00 & 439.61 & 556.67 & 346.48 & 10.49 & 7.89 & 1688 & 2524 \\
\hline Min & 33.66 & 5.83 & 37.27 & 4.17 & 30.48 & 52.90 & 120.78 & 0.11 & 7.12 & 308 & 452 \\
\hline Std-Dev & 43.09 & 22.61 & 73.54 & 7.34 & 127.68 & 152.39 & 47.96 & 2.06 & 0.17 & 432 & 652 \\
\hline JORADP 2011 & $100-200$ & $50-150$ & 200 & 12 & $250-400$ & $250-500$ & - & 50 & $6.5-8.5$ & 1500 & 2800 \\
\hline WHO 2011 & $75-200$ & $30-150$ & 200 & 12 & $200-400$ & $200-500$ & 120 & 50 & $6.5-8.5$ & 500 & 1500 \\
\hline
\end{tabular}




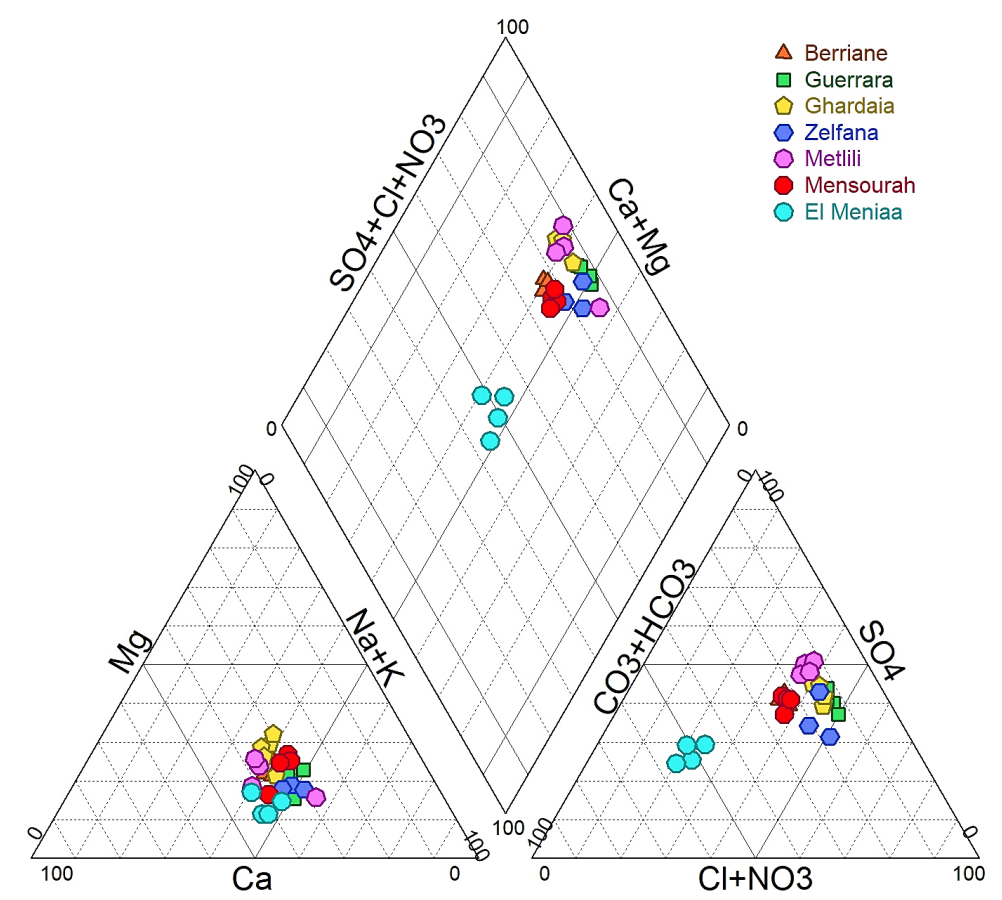

Figure 3. Piper diagram for the CI waters of Ghardaïa

which is explained by the participation of these elements in the acquisition of the salt charge of the CI groundwater.

The $\mathrm{Na}^{+} v$ s. $\mathrm{Cl}^{-}$correlation (Fig. 4a) shows a good correlation $(\mathrm{r}=0.94)$ between $\mathrm{Na}^{+}$and $\mathrm{Cl}^{-}$ ions. It can be seen that the majority of the points align with the halite dissolution line, confirming the halite dissolution process. However, some points show an excess of $\mathrm{Na}^{+}$or $\mathrm{Cl}^{-}$. This can be explained by the existence of another origin of $\mathrm{Na}^{+}$and $\mathrm{Cl}^{-}$. The positive correlation between $\mathrm{Ca}^{2+}$ and $\mathrm{SO}_{4}{ }^{2-}(\mathrm{r}=0.95)$ (Fig. $\left.4 \mathrm{~b}\right)$ suggests that dissolution of anhydrite and/or gypsum is another major salinization process. Indeed, the saturation indices show that all samples are undersaturated with respect to gypsum and anhydrite (Fig. 5).
The high correlation values between $\mathrm{Mg}^{2+}$ and $\mathrm{Ca}^{2+}$ vs. $\mathrm{Cl}^{-}$concentrations $(\mathrm{r}=0.81$ and $\mathrm{r}=90$ respectively) (Fig. 4c and Fig. 4d) cannot be related to any of the recognized salinization processes. They are related to cationic exchange processes, which become more evident in the clay mineral-rich intercalated continental aquifer reservoir. The $\mathrm{Na}^{+} v s . \mathrm{SO}_{4}^{2-}$ correlation (Fig. 4e) shows a proportional evolution of sulfate and sodium $(r=0.89)$, indicating another origin of sulfate than gypsum and anhydrite, namely the dissolution of thenardite $\left(\mathrm{Na}_{2} \mathrm{SO}_{4}\right)$ (Kamel and al., 2013). The good correlation between $\mathrm{Mg}^{2+}$ and $\mathrm{SO}_{4}^{2-}(\mathrm{r}=0.87)$ suggests that some of the $\mathrm{SO}_{4}^{2-}$ and $\mathrm{Mg}^{2+}$ may also be derived by weathering of the magnesium sulfate mineral $\left(\mathrm{MgSO}_{4}\right)$ (Fig. $\left.4 \mathrm{f}\right)$.

Table 2. Correlation matrix applied to the CI groundwater data

\begin{tabular}{|l|c|c|c|c|c|c|c|c|c|c|}
\hline Parameters & TDS & $\mathrm{EC}$ & $\mathrm{Ca}^{2+}$ & $\mathrm{Mg}^{2+}$ & $\mathrm{Na}^{+}$ & $\mathrm{K}^{+}$ & $\mathrm{HCO}_{3}^{-}$ & $\mathrm{Cl}^{-}$ & $\mathrm{SO}_{4}^{2-}$ & $\mathrm{NO}_{3}^{-}$ \\
\hline $\mathrm{TDS}$ & 1 & & & & & & & & & \\
\hline $\mathrm{EC}$ & 0.97 & 1 & & & & & & & & \\
\hline $\mathrm{Ca}^{2+}$ & 0.95 & 0.95 & 1 & & & & & & & \\
\hline $\mathrm{Mg}^{2+}$ & 0.85 & 0.86 & 0.83 & 1 & & & & & & \\
\hline $\mathrm{Na}^{+}$ & 0.95 & 0.96 & 0.87 & 0.71 & 1 & & & & & \\
\hline $\mathrm{K}^{+}$ & 0.6 & 0.61 & 0.56 & 0.43 & 0.6 & 1 & & & & \\
\hline $\mathrm{HCO}_{3}^{-}$ & 0.57 & 0.54 & 0.43 & 0.39 & 0.48 & 0.27 & 1 & & & \\
\hline $\mathrm{Cl}^{-}$ & 0.97 & 0.97 & 0.90 & 0.81 & 0.94 & 0.63 & 0.55 & 1 & & \\
\hline $\mathrm{SO}_{4}{ }^{2-}$ & 0.96 & 0.96 & 0.95 & 0.87 & 0.89 & 0.54 & 0.41 & 0.88 & 1 & \\
\hline $\mathrm{NO}_{3}^{-}$ & 0.14 & 0.15 & 0.13 & 0.29 & 0.11 & 0.11 & 0.11 & 0.2 & 0.06 & 1 \\
\hline
\end{tabular}



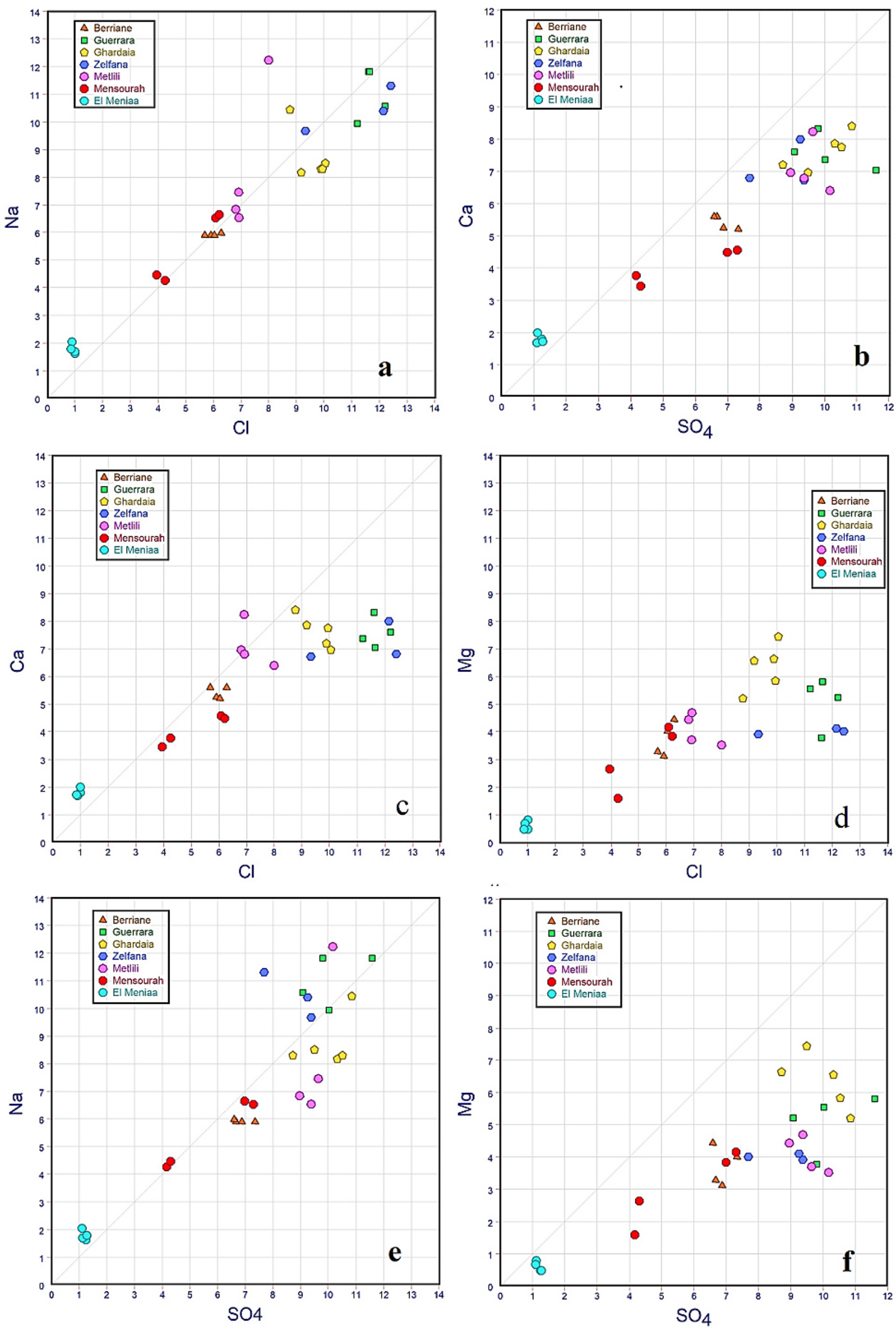

Figure 4. Relationships between major elements in sampled waters: (a) $\mathrm{Na}$ vs. $\mathrm{Cl}$; (b) Ca vs. $\mathrm{SO}_{4}$; (c) Ca vs. Cl; (d) $\mathrm{Mg}$ vs. Cl; (e) $\mathrm{Na}$ vs. $\mathrm{SO}_{4}$; (f) $\mathrm{Mg}$ vs. $\mathrm{SO}_{4}$ 
The calculation of saturation indices (Fig. 5) of the main minerals by PHREEQC software illustrates that the waters of the continental intercalare aquifer are undersaturated with respect to these minerals. The carbonate minerals have different degrees of saturation. Indeed, calcite saturation varies from -0.81 to -0.20 , and that of dolomite varies from -0.2 .06 to -0.30 . Evoporitic minerals show lower saturation levels than carbonate minerals. Gypsum shows saturation indices ranging from -2.12 to -088 , followed by anhydrite with indices ranging from -1.1 to -2.34 , and finally halite with indices ranging from -7.44 to -5.60 . The samples from the regions of El Meniaa and Menssoura present very low saturation indices due to the low mineralization of the waters.

\section{Quality of $\mathrm{Cl}$ water to potability}

From the point of view of water potability, the comparison between the results of chemical analyses carried out on water samples from the continental aquifer of the different localities of Ghardaiia and the guide values of the World Health Organization standards (WHO 2011) and Algerian standards (JORADP 2011) for drinking water (Table 1), illustrates that the groundwater of the investigated area is mostly potable. The study shows that only a few chemical elements present concentrations slightly exceed the recommended standards (TDS, $\mathrm{K}^{+}$and $\mathrm{SO}_{4}^{2-}$ ) (Table 1).

A second method was used to determine water quality better, the Water Quality Index (WQI) method. This method was first proposed by Horton (1965) in the United States. The technique has been widely applied and accepted in many countries, as it reflects the considerable importance and influence of the parameters examined on water quality for a particular use. During the development of WQI by various scientists, several mathematical methods were discovered (Banda et al. 2020).

One of the most widely used methods to assess groundwater quality is the arithmetic mean water quality index (Abbasnia A al. 2018; TliliZrelli and al. 2018). Physicochemical water parameters provide the most effective and useful way to describe groundwater conditions in a confined aquifer. The method includes three steps:

(1) Give a weighting to each parameter based on its potential to affect human health. Thus, the parameters' weights are assigned according to the values inversely proportional to the respective recommended regulatory standards. The relative weight (Wi) is calculated according to equation (7):

$$
W i=w i / \sum w i
$$

where: $W i$ is the weight of the respective parameter, wi is the relative weight (Table 3), and

$n$ is the number of parameters.

(2) Calculate the quality rating scale for each of the parameters considered. The quality assessment scale (qi) is calculated by equation 8 :

$$
q i=(\mathrm{ci} / \mathrm{si}) * 100
$$

where: $q i$ is the quality rating scale,

$\mathrm{Ci}$ is the concentration of the respective chemical parameter in each water sample in $\mathrm{mg} / \mathrm{l}$, and

$S i$ is the Algerian standard for drinking water (Table 3).

(3) Calculate the sub-indices (SI) for each parameter and generate the water quality index

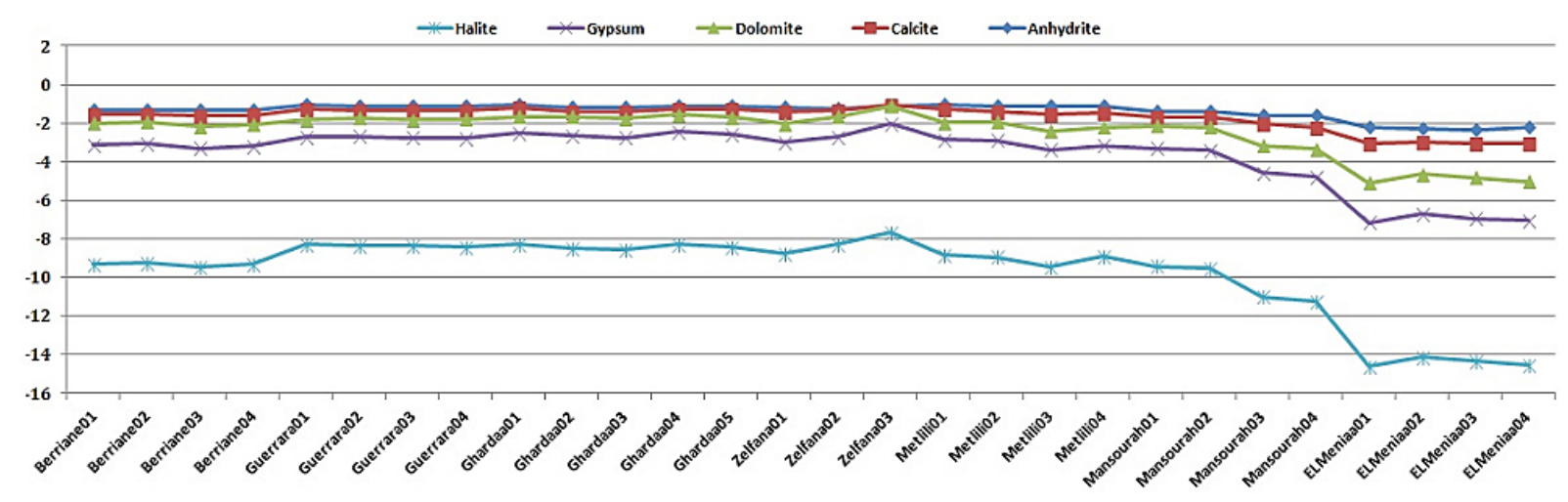

Figure 5. Water saturation indices of the CI aquifer in the Ghardaïa region 
by summing all the sub-index values (equation 9). SI is first determined for each chemical parameter and then calculated according to the WQI formula (10):

$$
S I i=w i^{*} q i
$$

and

$$
W Q I=\sum S I i
$$

where: $S I i$ is the sub-index of the ith parameter, $q i$ is the evaluation based on the concentration of the ith parameter, and $n$ is the number of parameters.

The calculated WQI values allow groundwater to be classified into five categories (Table 4): excellent, good, poor, very poor, and unfit for consumption.

The values of the water quality index (WQI) calculated for the waters of the continental intercalare aquifer of the study area vary between 44.35 (E1 Meniaa 04) and 168.77 (Guerrara 03) (Table 4). Three water quality classes were determined (Table 4 and Fig. 6); the excellent class represents $14.28 \%$ of the samples analyzed and includes four (4) boreholes in the El Meniaa region. The good class represents $7.14 \%$ of the analyzed samples and includes two boreholes in the Mansourah region. The rest of the analyzed boreholes (twenty-two boreholes) are in the poor class. They represent $78.52 \%$ of the analyzed samples.

\section{Water suitability for agricultural use}

Mineral salts contained in water in quantities have adverse effects on soil and plants. They can disturb the development of plants, act on the osmotic process, causing metabolic reactions. They also induce changes in the soil structure (on its permeability and aeration), directly affecting the development of the plant. Therefore, it is imperative in this case to study the parameters defining irrigation waters, such as the total concentration of dissolved salt in the water (electrical conductivity), the actual concentration of $\mathrm{Na}+$ in relation to other cations ( $\% \mathrm{Na}$ and SAR), the Kelly ratio $(\mathrm{KR})$, the permeability index (PI) and the magnesium hazard (MH)

Electrical conductivity (EC) is a very important parameter for assessing the suitability of groundwater for irrigation. EC is an indicator of the presence of salt in water (Ayers and Westcott, 1985) and determines the risk of salinity to crops when using water for irrigation. The electrical conductivity (EC) measured in the water samples taken in the study area (Table 1) shows a wide variation ranging from $452 \mathrm{~S} / \mathrm{cm}$ to $2524 \mathrm{~S} / \mathrm{cm}$ in the study area. The Wilcox (1955) classification (Table 5) revealed that $21.43 \%$ of the samples were very high salinity, $64.29 \%$ were high salinity, and $14.28 \%$ were medium salinity.

The percentage of sodium is a common factor in the evaluation of natural waters for irrigation. Sodium influences the physical and chemical properties of the soil and can significantly affect soil permeability and infiltration processes. When the concentration of sodium is very high, the soil becomes solid and compact. This affects the soil structure and leads to reduced rates of air and water leakage into the soil. The $\% \mathrm{Na}$ values ranged from (13.9) to (50.9) in the water samples studied. The Wilcox (1955) classification (Table 5) reveals that $57.15 \%$ of the samples were of acceptable quality for irrigation, and $42.85 \%$ were of good quality for irrigation. Sodium risk

Table 3. Weight of the parameters used in the WQI calculation

\begin{tabular}{|l|c|c|c|}
\hline Parameters & Weight (wi) & $\begin{array}{c}\text { JORADP } \\
2011(\mathrm{Si})\end{array}$ & $\begin{array}{c}\text { Relative } \\
\text { weight (Wi) }\end{array}$ \\
\hline $\mathrm{pH}$ & 4 & 8.5 & 0.114 \\
\hline $\mathrm{EC}$ & 4 & 1500 & 0.114 \\
\hline $\mathrm{TDS}$ & 5 & 500 & 0.114 \\
\hline $\mathrm{Ca}^{2+}$ & 2 & 75 & 0.057 \\
\hline $\mathrm{Mg}^{2+}$ & 1 & 50 & 0.028 \\
\hline $\mathrm{Na}^{+}$ & 2 & 200 & 0.057 \\
\hline $\mathrm{K}^{+}$ & 2 & 12 & 0.057 \\
\hline $\mathrm{HCO}_{3}{ }^{-}$ & 3 & 120 & 0.085 \\
\hline $\mathrm{Cl}^{-}$ & 3 & 250 & 0.085 \\
\hline $\mathrm{SO}_{4}{ }^{2-}$ & 4 & 250 & 0.114 \\
\hline $\mathrm{NO}_{3}^{-}$ & 5 & 50 & 0.114 \\
\hline $\mathrm{Total}^{-}$ & 35 & - & 1 \\
\hline
\end{tabular}

Table 4. Groundwater quality classification based on WQI

\begin{tabular}{|l|c|c|c|}
\hline \multicolumn{1}{|c|}{ Class } & WQI Index & $\begin{array}{c}\text { Number of } \\
\text { samples }\end{array}$ & $\begin{array}{c}(\%) \text { of } \\
\text { samples }\end{array}$ \\
\hline Excellent & $(<50)$ & 04 & 14.28 \\
\hline Good & $(51-100)$ & 02 & 7.14 \\
\hline Poor & $(101-200)$ & 22 & 78.52 \\
\hline Very poor & $(201-300)$ & 00 & 00 \\
\hline $\begin{array}{l}\text { unfit for } \\
\text { consumption }\end{array}$ & $(>301)$ & 00 & 00 \\
\hline
\end{tabular}




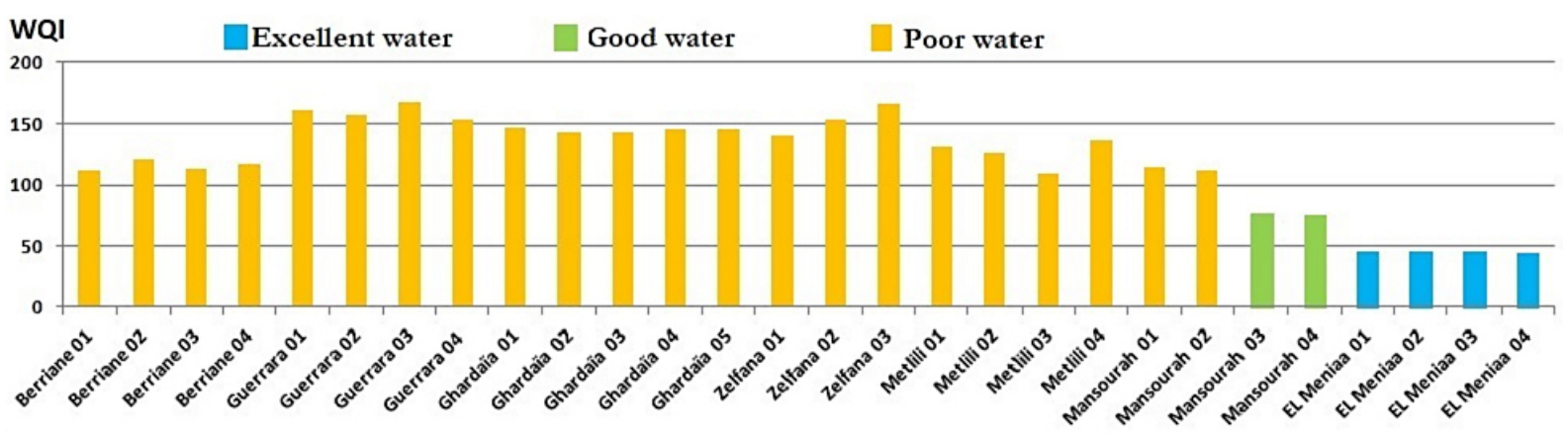

Figure 6. Histogram of the water quality index (WQI) of the waters of Ghardaïa CT

is also determined by calculating the sodium adsorption ratio (SAR) (Equation 3). SAR values play an important role in irrigation water because of the amount of sodium present in the soil after absorption. A high sodium concentration tends to decrease the permeability of the soil and degrade its structure. According to the classification established by Richards (1954) (Table 5), the water of the continental intercalare aquifer is of excellent quality for irrigation.

The representation of the samples on the Richards diagram (1954) shows that they are arranged in three classes (Fig. 7a); class $\mathrm{C}_{4} \mathrm{~S}_{2}$ indicates water of poor quality, it is highly mineralized, it can be used only to irrigate salt-tolerant plants. This class includes the CI waters of Guerrara, Zelfana, and some boreholes in the city of Ghardaiia. Class $\mathrm{C}_{3} \mathrm{~S}_{2}$ and $\mathrm{C}_{3} \mathrm{~S}_{1}$ indicate waters of acceptable quality, but the salinity must be controlled. This class includes the waters of Metlili, Mansourah, Berriane, and two boreholes in the city of Ghardaïa.

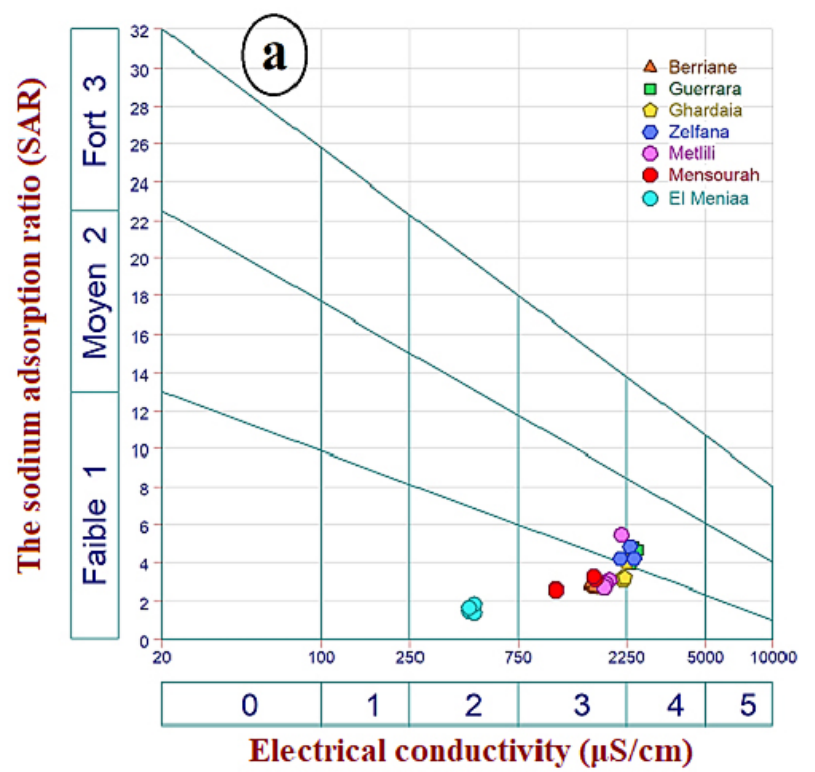

Finally, class $\mathrm{C}_{2} \mathrm{~S}_{1}$ indicates good quality water, represented by the waters of the E1 Meniaa region.

The classification of waters was made according to the method of Wilcox (1955) based on the representation of electrical conductivity (EC) values according to the percentage of sodium (\% Na). The Wilcox diagram (Fig. 7b) shows that the waters of the study area are grouped into three classes: the excellent class represented by the boreholes of El Meniaa, the good class includes the boreholes of Menssoura, Berriane and Metlili, and the mediocre class includes the boreholes of Ghardaïa, Zelfana, and Guerrara.

The Kelly ratio (1963) is another important parameter that is practiced to obtain details on groundwater quality, considering the concentration of $\mathrm{Na}^{+}$in relation to $\mathrm{Ca}^{2+}$ and $\mathrm{Mg}^{2+}$. The Kelly ratio is calculated by Equation 4. A Kelly index with values higher than 2 is qualified as unsuitable for irrigation. When the Kelly index is between 1 and 2, the water is poor for irrigation,

Figure 7. Richards diagram and (a) Wilcox diagram (b) of CI waters of Ghardaïa 
Table 5. Classification of groundwater samples for irrigation purposes

\begin{tabular}{|c|c|c|c|c|}
\hline Parameter & Range & Water class & $\begin{array}{c}\text { Nomber of } \\
\text { samples }\end{array}$ & $\begin{array}{c}\% \text { of } \\
\text { samples }\end{array}$ \\
\hline $\mathrm{EC}(\mu \mathrm{S} / \mathrm{cm})($ Wilcox 1955) & $\begin{array}{c}<250 \\
250-750 \\
750-2250 \\
>2250\end{array}$ & $\begin{array}{l}\text { Low salinity hazards (good) } \\
\text { Medium salinity hazard (moderate) } \\
\text { High salinity hazard (poor) } \\
\text { Very high salinity hazard (very poor) }\end{array}$ & $\begin{array}{l}00 \\
04 \\
18 \\
06\end{array}$ & $\begin{array}{c}00 \\
14.28 \\
64.29 \\
21.43\end{array}$ \\
\hline \% Na (Wilcox 1955) & $\begin{array}{c}0-20 \\
20-40 \\
40-60 \\
60-80 \\
>80\end{array}$ & $\begin{array}{l}\text { Excellent } \\
\text { Good } \\
\text { Permissible } \\
\text { Doubtful } \\
\text { Unsuitable }\end{array}$ & $\begin{array}{l}00 \\
12 \\
16 \\
00 \\
00\end{array}$ & $\begin{array}{c}00 \\
42.85 \\
57.15 \\
00 \\
00 \\
\end{array}$ \\
\hline SAR (meq/l) (Richards 1954) & $\begin{array}{c}0-10 \\
10-18 \\
18-26 \\
>26 \\
\end{array}$ & $\begin{array}{l}\text { Excellent } \\
\text { Good } \\
\text { Doubtful } \\
\text { Unsuitable }\end{array}$ & $\begin{array}{l}28 \\
00 \\
00 \\
00\end{array}$ & $\begin{array}{c}100 \\
00 \\
00 \\
00\end{array}$ \\
\hline RK (Kelley 1963) & $\begin{array}{l}<1 \\
1-2 \\
>2\end{array}$ & $\begin{array}{c}\text { Good } \\
\text { Doubtful } \\
\text { Unsuitable }\end{array}$ & $\begin{array}{l}26 \\
02 \\
00\end{array}$ & $\begin{array}{c}92.86 \\
7.14 \\
00\end{array}$ \\
\hline PI (\%) (Doneen 1964) & $\begin{array}{l}>75 \\
75-25 \\
<25\end{array}$ & $\begin{array}{c}\text { Max. permeability } \\
75 \% \text { of max. permeability } \\
25 \% \text { of max. permeability }\end{array}$ & $\begin{array}{l}03 \\
25 \\
00\end{array}$ & $\begin{array}{c}10.71 \\
89.29 \\
00\end{array}$ \\
\hline RM (\%) (Ragunath 1987) & $\begin{array}{l}<50 \% \\
>50 \%\end{array}$ & $\begin{array}{c}\text { Suitable } \\
\text { Unsuitable }\end{array}$ & $\begin{array}{l}27 \\
01\end{array}$ & $\begin{array}{l}96.43 \\
03.57\end{array}$ \\
\hline
\end{tabular}

while an index lower than 1 is considered suitable for irrigation. The calculated values in the study area (Table 5) give that $92.86 \%$ of the samples are in the good class for irrigation and $7.14 \%$ in the poor class for irrigation.

Soil permeability is an important factor in allowing groundwater to infiltrate. The permeability index (PI) parameter calculated by Equation 5 is used to assess the suitability of groundwater for irrigation purposes. According to Doneen (1964), PI values are classified into three classes: class 1 excellent, class 2 good, and class 3. Class 1 and 2 groundwaters are considered good for irrigation with $75 \%$ or more maximum permeability, and class III groundwaters are unsuitable with $25 \%$ maximum permeability. The calculated permeability index values in the study area (Table 5) indicate that all groundwater samples are suitable for irrigation.

The concentration of magnesium and calcium in groundwater also plays a key role in determining groundwater quality. When the magnesium hazard ratio (MR) in irrigation water is higher than $50 \%$, soils become more alkaline, which reduces crop yield. Raghunath (1987) developed a ratio to calculate MR (Equation 6). On this basis, the calculated values were classified into two classes, suitable and unsuitable. Values below 50 were considered suitable, and values above 50 were considered unsuitable for irrigation purposes. The calculated magnesium ratio values in the study area (Table 5) indicate that $96.43 \%$ of groundwater samples are suitable for irrigation.

\section{CONCLUSION}

In this study, the suitability of groundwater as a primary resource for drinking and irrigation was investigated in the Ghardaiia region. According to the results, the CI waters are dominated by three facies; sodium sulfate, sodium chloride, and sodium bicarbonate. The electrical conductivity (EC) varies between 452 and $2524 \mu \mathrm{S} / \mathrm{cm}$, and the TDS varies between 308 and $1688 \mathrm{mg} / \mathrm{l}$. The lowest values of EC and TDS were found in the El Meniaa area. The geochemical study shows that the mineralization of water is linked to the dissolution of evaporites (gypsum and halite in particular) and the phenomenon of base exchange.

The water of the continental intercalare aquifer of Ghardaiia is potable according to the potability standards of the World Health Organization (WHO) and Algeria. The use of the water quality index (WQI) method shows three classes of water quality. We distinguish the excellent class $(14.28 \%)$, which includes the four boreholes of El Meniaa, the good class (7.14\%), which is presented by two boreholes in the region of Mansourah, and the bad class (78.58\%), which includes the rest of the boreholes analyzed. The quality of the agricultural water was evaluated using the following parameters: EC, SAR, Na\%, KR, PI and MH. The results show that the waters of the continental intercalare aquifer are generally of good quality for irrigation. However, the high salinity of the waters requires good drainage of the cultivated soils. 


\section{REFERENCES}

1. Abbasnia A., Yousefi N., Mahvi A.H., Nabizadeh R., Radfard M., Yousefi M., Alimohammadi M. 2018. Evaluation of groundwater quality using water quality index and its suitability for assessing water for drinking and irrigation purposes: case study of Sistan and Baluchistan province (Iran). Human and Ecological Risk Assessment: An International Journal, 1-18. DOI: 10.1080/10807039.2018.1458

2. Adimalla N., Ratnakar D., Anusree K., Ajay K.T. 2020. Appraisal of Groundwater Quality for Drinking and Irrigation Purposes in Central Telangana, India. Groundwater for Sustainable Development, 10(126), 100334. DOI: 10.1016/j.gsd.2020.100334.

3. Ayers R.S. \& Westcott D.W. 1985. Water quality for agriculture, Food and Agriculture Organization of the United Nations, Rome, Italy, 29.

4. Banda T.D. \& Muthukrishna V.K. 2020. Development of Water Quality Indices (WQIs): A Review. Polish Journal of Environmental Studies, 29(3), 2011-2021. DOI: 10.15244/pjoes/110526.

5. Bouselsal B. 2017. Groundwater quality in arid regions: the case of Hassi Messaoud region (SE Algeria). J. Fundam. Appl. Sci., 2017, 9(1), 528-541. DOI: $10.4314 /$ jfas.v9i1.30

6. Bouselsal B. \& et Belksier M.S. 2018. Caractérisation géochimique de l'aquifère de Complexe Terminal de El-Oued (SE Algérie). Journal International Sciences et Technique de l'Eau et de l'Environnement. 3(1), 74-80.

7. Dhaouadi L., Houda B., Fatma W., Nissaf K., Naima B.B., Mohamed A.W., Yaohu K.K. 2020. Agriculture Sustainability in Arid Lands of Southern Tunisia: Ecological Impacts of Irrigation Water Quality and Human Practices. Irrigation and Drainage, 69(5), 974-996. DOI: 10.1002/ird.2492.

8. Kamel S., Mohamed B.C., Younes J. 2013. Investigation of Sulphate Origins in the Jeffara Aquifer, Southeastern Tunisia: A Geochemical Approach. Journal of Earth System Science, 122(1), 15-28. DOI: $10.1007 /$ s12040-012-0252-0.

9. Doneen L.D. 1964. Water Quality for Agriculture. Department of Irrigation, University of Calfornia, Davis, 48.

10. Hakimi Y., Orban P., Deschamps P., Brouyere S. 2020. Hydrochemical and isotopic characteristics of groundwater in the Continental Intercalaire aquifer system: Insights from Mzab Ridge and surrounding regions, North of the Algerian Sahara. Journal of Hydrology: Regional Studies, 34, 100791. DOI: 10.1016/j.ejrh.2021.100791.
11. Horton R.K. 1965. An index number system for rating water quality. Journal - Water Pollution Control Federation, 37, 300-305.

12. JORADP. 2011. Décret exécutif $n^{\circ} 11-125$ du 22 mars 2011, relatif à la qualité de l'eau de consommation humaine. Journal officiel de la république algérienne.

13. Kelly W.P. 1940. Permissible composition and concentration of irrigation waters. Proc Amer Soc Civ Engin, 66, 607-613.

14. ONM. 2018. Bulletins mensuels de relevé des paramtres climatologiques en Algérie (période 2000-2020), Ofce national météorologique, Ghardaïa, Algérie.

15. OSS (Observatoire Sahara et Sahel). 2003. Système aquifère du Sahara septentrional: gestion commune d'un bassin transfrontière. Rapport de synthèse. OSS, Tunisie, 322.

16. Parkhurst D. \& Appelo C. 1999. User's guide to PHREEQC (Version 2) - A computer program for speciation, batch-reaction, one-dimensional transport, and inverse geochemical calculations. WaterResources Investigation Report 99-4259. Denver, Colorado: U.S. Department of the Interior, U.S. Geological Survey.

17. Piper A.M. 1944. Graphical interpretation of water analysis. Transactions of the American Geophysical Union., 25, 914-923.

18. Raghunath H.M. 1987. Groundwater. Wiley Eastern Ltd., Delhi.

19. Richards L.A. 1954. Diagnosis and improvement of saline and alkali soils. US Department of Agriculture, Hand Book No. 60. Government Printing Offce, Washington, D.C., 160.

20. Satouh A., Bouselsal A., Chellat S., Benaabidate I. 2021. Determination of Groundwater Vulnerability Using the DRASTIC Method in Ouargla Shallow Aquifer (Algerian Sahara). Journal of Ecological Engineering, 22(6), 1-8. DOI: $10.12911 / 22998993 / 137680$.

21. Tlili-Zrelli B., Moncef G., Rachida B. 2018. Spatial and Temporal Variations of Water Quality of Mateur Aquifer (Northeastern Tunisia): Suitability for Irrigation and Drinking Purposes. Journal of Chemistry 2018. DOI: $10.1155 / 2018 / 2408632$.

22. WHO (World Health Organization). 2011. Guidelines for Drinking Water Quality, 4th Ed. NLM Classification, WA 675, World Health Organization, Geneva, Switzerland, 307-433.

23. XLSATAT. 2014. Logiciel version 2014.5.03 downloadable at http://www.xlstat.com/info@xlstat.com. 